\title{
The effect of light acclimation of single leaves on whole tree growth and competition - an application of the tree growth model ALMIS
}

\author{
Christiane Eschenbach* \\ Ecology Center of the University of Kiel, Schauenburger Str. 112, D-24118 Kiel, Germany
}

(Received 29 June 1999; accepted 15 February 2000)

\begin{abstract}
Black alder (Alnus glutinosa L. (Gaertn.)) is a light-demanding, fast growing tree species, widespread but always restricted to wet habitats. Because no sun and shade leaves can be distinguished within the alder crown, the question arises whether these specific photosynthetic characteristics may contribute to alder's low competitiveness. A functional-structural tree growth model ("ALMIS"), based on an object oriented approach, was developed and parameterized using data from extensive investigations of an alder forest in Northern Germany. The basic model structure is described, especially focusing on carbon dynamics. ALMIS was used to study the effects of light acclimation of single leaves on whole plant growth and competition. Different photosynthetic types were simulated to grow either in isolation or in competition which each other. When grown in isolation over an extended period, a model tree with exclusively shade leaves accumulated less total biomass than one with exclusively sun leaves, but a tree with the capacity to acclimate the leaves to the low light conditions in the inner crown grew the most. Inter-tree competition enhanced the advantage of leaf acclimation for whole plant growth.
\end{abstract}

functional-structural growth model / photosynthesis / acclimation / shade leaves / Alnus glutinosa

Résumé - Effets de l'adaptation des feuilles à la lumière sur la croissance globale de l'arbre et la compétition - une application du modèle de croissance ALMIS. L'Aulne noir (Alnus glutinosa L. (Gaertn.)) est une espèce à croissance rapide exigeante en lumière. Elle est répandue, mais toujours localisée aux habitats humides. Comme il n'est pas possible de différencier dans la canopée les feuilles d'ombre de celles de lumière, la question se pose de savoir si ses caractéristiques photosynthétiques peuvent contribuer à la faible compétitivité de l'Aulne. Un modèle de croissance à fonction structurelle (ALMIS), basé sur l'approche orientée objet, a été développé et paramétrisé à partir des données résultant d'une investigation extensive dans une forêt d'aulne dans le Nord de l'Allemagne. La structure du modèle de base est décrite, spécialement pour la partie dynamique du carbone. ALMIS a été utilisé pour étudier les effets de l'adaptation des feuilles à la lumière sur la croissance globale et la compétition. Différentes conditions photosynthétiques ont été simulées pour la croissance, soit en condition isolée, soit en condition de compétition entre elles. Dans le cas de la croissance en condition isolée pour une longue période, le modèle d'arbre avec uniquement des feuilles d'ombre accumule moins de biomasse totale que ceux avec uniquement des feuilles de lumière. Mais un arbre qui aurait la capacité d'adaptation de ses feuilles aux conditions de lumière au sein de sa canopée aurait une meilleure croissance. La compétition entre arbre améliore les avantages de l'adaptation des feuilles vis-à-vis de la croissance globale de la plante.

modèle de croissance à fonction structurelle / photosynthèse / adaptation / feuilles d'ombre / Alnus glutinosa

* Correspondence and reprints

Tel. +431 880-4035; Fax.+431 880-4083; e-mail: christia@pz-oekosys.uni-kiel.de 


\section{INTRODUCTION}

Acclimation, as a phenotypic response to different combinations of environmental factors, is a well known phenomenon in plant (eco)physiology [29]. Structural and physiological acclimation to the prevailing climatic conditions enhances the productivity of plant species within their own environment. The ability of plants to acclimate contributes to their competitiveness under varying conditions, but their capacity to do so varies among different species.

In a tree crown, single leaves are exposed to spatially varying microclimatic conditions, most evident in the variation of irradiance due to mutual shading. Accordingly, many tree species, like other plant types, exhibit spatially varying acclimation of leaves within the crown. Sun and shade leaves are formed, which differ in anatomical, biochemical, and physiological features [e.g. 4, 5, 22, 31]. For example, such differences were observed in Fagus sylvatica, Quercus robur and Acer saccharum [8, 13, 38]. For trees of a given leaf area, shade acclimation has been shown to enhance carbon gain of the whole plant [2, 7, 35].

For black alder (Alnus glutinosa (L.) Gaertn.) however, we found from intensive field investigations that the leaves in different positions of the crown rarely show any acclimation of leaf physiological properties dealing with carbon assimilation $[14,16]$. Photosynthetic leaf properties, such as chlorophyll content and chlorophyll $\mathrm{a} / \mathrm{b}$, do not differ significantly within the alder canopy. $\mathrm{CO}_{2}$ exchange and dependence of net photosynthesis on microclimatic conditions were nearly identical for peripheral leaves and those of the inner crown. No "sun" and "shade" leaves could be discerned, with respect to the maximum assimilation rate or the initial slope of the photosynthetic light curve. Concerning stomatal conductance however, leaves of the inner crown were slightly adapted to the prevailing lower PPFD, in that their stomatal opening reacted more sensitively to irradiance.

Black alder grows up to a height of about $20-30 \mathrm{~m}$ and reaches an age of 100-120 years. The species is widespread in Europe and adjacent regions. However, within this large range black alder is never the dominating tree species in the broad-leaved forests at medium sites, but is restricted to moderate or extremely wet habitats. Black alder is also known to be light demanding and a representative of early successional forest phases [e.g. 12, 23].

During our investigations, the question arose whether the absence of photosynthetic acclimation in the alder leaves may contribute to this species' low competitiveness.
For large and long-lived species such as trees, the long-term effects of acclimation phenomena on whole plant growth cannot easily be investigated experimentally. Simulation models provide a useful tool to describe and study such effects. Previous studies dealing with plant acclimation to different light environments have focused on leaf photosynthetic responses [e.g. 19, 30]. However, the long-term implications for tree growth and competition have received less attention. Over the last few years, "functional-structural tree growth" models have been developed which attempt to link tree physiology and architecture within an ecophysiological framework [11, 20, 25, 40]. Recently, 3-D-models incorporating physiological features have been specifically designed to relate competition to structural features [27, 32]. However, to my knowledge, such modelling approaches have not yet been used to study the integrated effect of photosynthetic acclimation on whole-tree growth and competition. The objective of the present study was to address this question.

Clearly, shade-adapted photosynthetic characteristics lead to an increased carbon gain of the shaded leaves, but the interesting issue is that this additionally gained carbon can be used to build more biomass and more carbon gaining leaves. On the other hand, it has to be considered, that an increased number of leaves leads to increased mutual shading. Thus, the effect of light acclimation of single leaves on whole tree growth is determined by the interrelations of the additional carbon gain and structural responses. Therefore, our structural-functional tree growth model (ALMIS), based on an object oriented approach, was used to explore the role of sunshade acclimation of individual leaves in the growth of whole trees, either in isolation or in competition. The study adresses the question whether the low competitiveness of black alder trees could be attributed to the observed absence of leaf acclimation to shade.

\section{MATERIALS AND METHODS}

\subsection{The model ALMIS}

\subsubsection{Study site and data base}

The model development and parameterization are based on data from extensive field investigations of an alder forest in the Bornhoeved Lakes Region (table I). The study site of the "Ecosystem Research in the Bornhoeved Lakes Region" is located in Northern Germany (Schleswig-Holstein, $54^{\circ} 06^{\prime} \mathrm{N}$ and $10^{\circ} 15^{\prime} \mathrm{E}$, $29 \mathrm{~m} \mathrm{NN}$ [26]). The alder forest is about $18 \mathrm{~m}$ high and 
Table I. Empirical basis for the elementary units and the functions of carbon dynamics $[14-17,21]$ and their mathematical realisation in ALMIS. Abbreviations are given in the lower panel.

\begin{tabular}{|c|c|c|}
\hline & $\begin{array}{l}\text { Variables, pools or } \\
\text { processes [units] }\end{array}$ & Measured variables [units] or derived equations \\
\hline Environment & microclimate & irradiance PPFD $\left[\mu \mathrm{mol} \mathrm{m}^{-2} \mathrm{~s}^{-1}\right]$, temperature $\left[{ }^{\circ} \mathrm{C}\right], \Delta W\left[\mathrm{mmol} \mathrm{mol}^{-1}\right]$ \\
\hline \multirow[t]{4}{*}{$\begin{array}{l}\text { Plant structure } \\
\text { and carbon pools }\end{array}$} & $\begin{array}{l}\text { foliage distribution } \\
\text { and foliage density }\end{array}$ & $\begin{array}{l}\text { leaf area index [dimensionless] } \\
\text { leaf area density }\left[\mathrm{m}^{2} \mathrm{~m}^{-3}\right]\end{array}$ \\
\hline & $\begin{array}{l}\text { dimensions of internodes, } \\
\text { leaves, roots }\end{array}$ & $\begin{array}{l}\text { length }[\mathrm{cm}], \text { radius }[\mathrm{cm}] \text {, volume }\left[\mathrm{cm}^{3}\right], \\
\text { surface area }\left[\mathrm{m}^{2}\right] \text {, angle from axis }\left[{ }^{\circ}\right]\end{array}$ \\
\hline & $\begin{array}{l}\text { structural dry matter } \\
\text { (structural pool) }\end{array}$ & biomass of leaves, branches, stem, roots $\left[\mathrm{g} \mathrm{m}^{-2}\right]$ \\
\hline & $\begin{array}{l}\text { non-structural dry matter } \\
\text { (assimilate pools, starch pools) }\end{array}$ & assimilate pools $\left[\mathrm{g} \mathrm{g}^{-1}\right.$ ], starch pools $\left[\mathrm{g} \mathrm{g}^{-1}\right]$ \\
\hline
\end{tabular}

\section{Carbon dynamics}

-uptake

-demand stomat. conductance $[\mathrm{mmol}$ $\mathrm{m}^{-2} \mathrm{~s}^{-1}$ ] dependent on $\Delta \mathrm{W}$

stomat. conductance

dependent on PPFD

net photosynthesis [ $\mu \mathrm{mol}$ $\mathrm{m}^{-2} \mathrm{~s}^{-1}$ ] dependent on PPFD

net photosynthesis dependent on temperature

net photosynthesis dependent on stomat. cond.

long-term transport

storage of long-term "starch" pools

and mobilisation of long-term "starch" pools

$$
\begin{aligned}
& G_{\mathrm{VPD}}=s 1+\frac{s 2}{\text { Delta } W} \\
& G_{1}=\left(G_{\max }-G_{\min }\right) *\left(1-\exp \left(\frac{-s 3 * I}{\left(G_{\max }-G_{\min }\right)}\right)\right)+G_{\min } \\
& A_{\mathrm{I}}=\left(A_{\max }-R\right) * \tan \mathrm{h}\left(\frac{k * I}{A_{\max }-R}\right)+R \\
& A_{\mathrm{T}}=\frac{A_{\mathrm{K}} *\left(-\left(T-T_{\mathrm{min}}\right)^{4}+2 *\left(T-T_{\mathrm{min}}\right)^{2} *\left(T_{\mathrm{opt}}-T_{\mathrm{min}}\right)^{2}\right)}{\left(T_{\mathrm{opt}}-T_{\mathrm{min}}\right)^{4}} \\
& A_{\mathrm{G}}=A_{\mathrm{K}} * \tanh \left(g * \frac{G}{A_{K}}\right) \\
& R_{\text {Target }}=R_{\text {Target }}+\left(P_{\text {Origin }} * c * \Delta_{\text {Time }}\right) \\
& R_{\text {Origin }}=R_{\text {Origin }}-\left(P_{\text {Origin }} * c * \Delta_{\text {Time }}\right) \\
& R_{\text {Starch }}=R_{\text {Starch }}+\left(P_{\text {Assim }} * c * \Delta_{\text {Time }}\right) \\
& \mathrm{R}_{\text {Assim }}^{\text {Starch }}=R_{\text {Assim }}-\left(P_{\text {Assim }}^{\text {Assim }} * c * \Delta_{\text {Time }}\right) \\
& R_{\text {Assim }}=R_{\text {Assim }}+\left(P_{\text {Starch }} * \mathrm{c} * \Delta_{\text {Time }}\right) \\
& R_{\text {Starch }}=R_{\text {Starch }}-\left(P_{\text {Starch }} * \mathrm{c} * \Delta_{\text {Time }}\right) \\
& R_{\text {Assim }}=R_{\text {Assim }}-\left(P_{\text {Struct }} * c * \Delta_{\text {Time }}\right) \\
& R_{\text {Struct }}=R_{\text {Struct }}+\left(P_{\text {Assim }} * c * \Delta_{\text {Time }}\right)
\end{aligned}
$$

leaf dark respiration $[\mu \mathrm{mol}$ $\mathrm{m}^{-2} \mathrm{~s}^{-1}$ ] dependent on temp.

respiration of internodes and roots

growth of leaves, internodes, and roots

$A_{\mathrm{G}}=$ dep. of assimilation on stomatal conductance; $A_{\mathrm{I}}=$ light dep. assimilation rate; $A_{\mathrm{K}}=$ capacity of net photosynthesis; $A_{\mathrm{max}}=$ maximum assimilation rate; $A_{\mathrm{T}}=$ temperature dep. assimilation rate; $c=$ constant; $\Delta_{\text {Time }}=$ time step of integration; $\Delta W=$ vapour pressure difference between leaf and ambient air; $G=$ stomatal conductance; $g=$ empirical coefficient (assimilation dep. on stomatal conductance); $G_{\mathrm{I}}=$ light dep. stomatal conductance; $G_{\max }=$ light saturated stomatal conductance; $G_{\min }=$ minimum stomatal conductance; $G_{\Delta W}=\Delta W$ dep. stomatal conductance; $I=$ irradiance (PPFD); $k=$ initial slope of the light-photosynthesis curve; $P_{\text {Assim }}=$ pool of assimilates; $P_{\text {Origin }}=$ origin pool; $P_{\text {Starch }}=$ pool of starch; $P_{\text {Struct }}=$ pool of structural fixed carbon; $R=$ leaf dark respiration; $R_{\mathrm{Assim}}=$ changes of assimilate pool by update; $R_{\text {Orinin }}=$ changes of origin pool by update; $R_{\mathrm{Stach}}=$ changes of starch pool by update; $R_{\text {Struct }}=$ changes of structure pool by update; $R_{\mathrm{T}}=$ temperature dep. dark respiration rate; $R_{\mathrm{Target}}=$ changes of target pool by update; $r 1, r 2=$ empirical coefficients (dark respiration); $s 1, s 2, s 3=$ empirical coefficients $\left(\right.$ stomatal conductance); $T=$ temperature; $T_{\min }=$ minimum temperature of photosynthesis; $T_{\mathrm{opt}}=$ optimum temperature of photosynthesis. 
60 years old, and was typified as an Alnetum glutinosae [37]. The stand forms a $30 \mathrm{~m}$ wide belt on temporarily water logged histosols developed from decomposed alder peat [36].

Continuous microclimatic measurements were made during the growing seasons at 10 min intervals and at different levels in the alder canopy. The present model runs are driven by 30 days' data collected in summer 1992, which for reasons of computation time were aggregated as mean values over 4 hours. Photosynthesis and light interception in the black alder stand are quantitatively well-known and well represented in the model, but the parameterization of other processes, such as carbon allocation and reserve storage, is based on data reported from other tree species or on qualitative knowledge $([21,33]$ table $I)$.

\subsubsection{Basic model structure}

The model ALMIS is based on a generic plant model, developed by Breckling $[6,18]$. The program code was written in the programming language SIMULA, which provides a event-scheduling concept and allows the simulation of quasi-parallel processes [9].

ALMIS describes the processes of tree growth as well as the development of the structures on which these processes occur. In an object oriented approach, the model uses a modular representation for each tree. The modules are represented by "objects", which are arranged in a hierarchical system. The different objects are all in constant communication via the transfer of information and materials [1].

ALMIS includes an "environment part" and a "plant part" $[6,18]$. The model trees, represented by the plant part (figure 1), consist of the objects Meristems, Leaves, Internodes, Roots, and Roottips, which have topological, dimensional and physiological properties, that are calculated each time step for each object. Each object consists of three pools: the assimilate pool, the non-structural reserve pool ("starch") and the pool of structural dry matter (figure 2). The maximum sizes of the pools depend on the variable dimensions of the object (e.g. length, radius, surface area), but the actual pool sizes result from the matter fluxes within the whole system.

The formation of new internodes and roots depends on the local supply of assimilates in the Meristem and Roottips, respectively. If the pool of assimilates exceeds a threshold, new tissues are initiated and transfer of a proportion of the assimilates pool to them occurs. Furthermore, Internodes and Roots can initiate new Meristems and Roottips to simulate branching. In general, the architecture of the tree is represented by a 3-

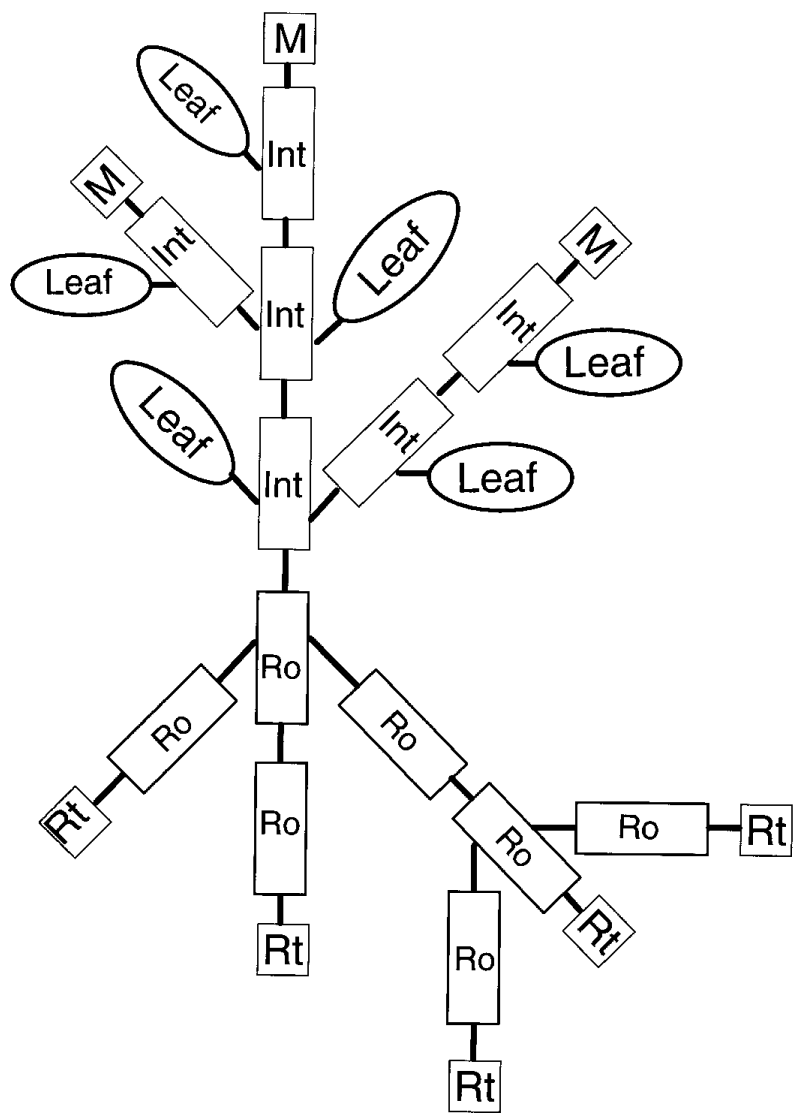

Figure 1. The basic structure of the plant part in ALMIS consists of the objects: Internodes (Int), Leaves (Leaf), Meristems (M), Roots (Ro), and Roottips (Rt). Interactions between objects are ensured by a system of mutual references.

dimensional branching structure which is generated recursively [6]. Via Meristems and Roottips, internode and root objects generate new branches at their terminal points. The new objects are the so called "successors" of the parent objects (which then are "predecessors"). The newly generated branches have particular initial dimensional and physiological properties and a particular branching angle. The number of branches, angles and the initial properties are specified in an input parameter data set. In the above ground architectural structure, one of the newly generated branches maintains orientation and thus prolongs the stem and the main branches (figure 1).

The environment part is divided into air segments and soil segments, within each of which local microclimatic state variables, such as temperature, air humidity and irradiance are given. In the present version of ALMIS, the environment is discretizised into eight steps in $x$ - and 

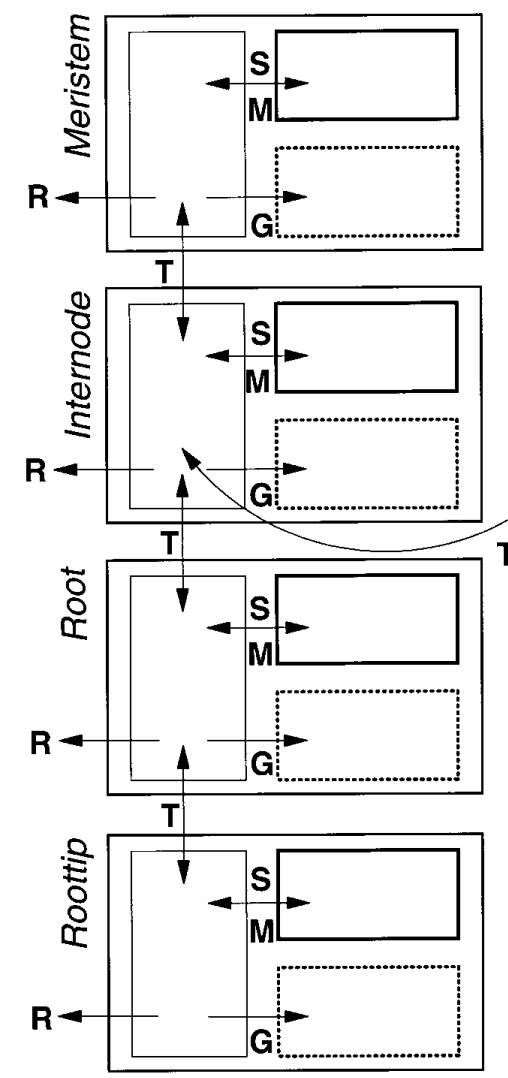

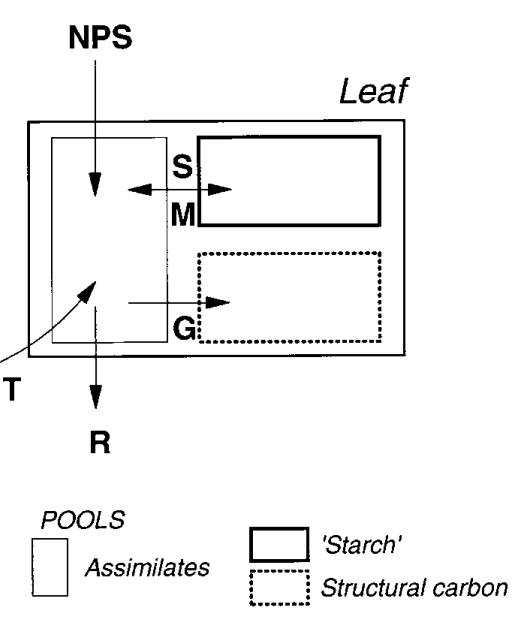

PROCEDURES NPS Photosynthesis

R Respiration

G Growth

T Long-term transport

S Storage

M Mobilisation
Figure 2. The pools and procedures for carbon flow in ALMIS. Pools and procedures are explained in the text. The equations of the shown relationships are given in table $I$. $y$-coordinate (= vertical axis), and into by 12 steps in $z$-coordinate (768 cubes).

The interactions between the single parts of the environment and the plant, and between the plant parts themselves, are ensured by a system of mutual references. This system of reference variables is used to manage the exchange of information and matter fluxes between the different modules. The references from particular plant objects to their corresponding space segment allow direct access to the respective environmental variables. Conversely, a plant object can modify the local environmental variables (e.g. by shading). As the growing plant is represented by a developing structure, these references must be continously updated.

Carbon dynamics were driven by microclimatic data, which were aggregated over four hours. However, as a consequence of the not yet mutually adjusted parameterization of the different processes, modeled plant growth does not reflect real growth. Therefore, time steps are considered as relative time steps instead of "hours" or "years".

\subsubsection{Carbon fluxes}

The present version of the model considers only the carbon dynamics of alder trees. Flows of water and nutrients are not considered. Carbon uptake and flow between the plant organs are modelled by the use of various procedures, which are used in combination (figure 2). The procedures used in ALMIS are briefly desribed in the following and the mathematical realisations of the relationships are given in table I.

Leaf photosynthesis depends on the ambient microclimatic conditions. The model describes the dependence of leaf photosynthesis on irradiance, temperature and air humidity (vapour pressure difference between leaf and ambient air, $\Delta W$ ). Leaf respiration is a function of temperature. Stomatal conductance is a function of irradiance and $\Delta W$. The dependence of net photosynthesis on stomatal conductance follows a saturation type curve. The arrangement of the relationships within the photosynthesis model is described elsewhere in more detail [15].

By a long-term transport procedure the gained assimilates are distributed among the different plant organs. 
According to the branch autonomy concept, the assimilate allocation is modelled at the organ level: at each time step, a proportion of the assimilate pool of an object is transported up (to the successor) and a different proportion is transported down (to the predecessor). Assimilation transport follows simple diffusion kinetics; it depends on the sizes of the assimilate pools and assumes fixed partitioning coefficients. The main components of carbon demand in the present model are respiration, structural growth and storage of non-structural dry matter. Respiration rates of the roots and internodes depend on the pools of structural dry matter. In structural growth, a fixed proportion of the assimilate pool is irreversibly shifted to the structural carbon pool. Assimilates are shifted reversibly between the assimilate pool and the reserve storage pool (starch) by a storage procedure and a counteracting mobilisation procedure. They are both depending on the pool sizes and on fixed partitioning coefficients.

Incident irradiance is assumed to be normal to the horizontal. The attenuation of irradiance within the tree canopy is a function of leaf area: irradiance in each cube is calculated according to the summed total leaf surface in the cubes above. The parameterization of the LambertBeer's equation [28] is based on irradiance data measured at various levels in an alder canopy (data not shown).

\subsection{Characterisation of different leaf types}

In the simulations, the growth of trees with different photosynthetic leaf types was compared in terms of differences in total biomass and number of leaves. As mentioned in the introduction, real alder leaves exhibit nearly identical photosynthetic characteristics throughout the tree canopy. However, to study the integrated effect of photosynthetic acclimation, in the different simulations measured alder characteristics and fictitious adaptive leaf photosynthetic characteristics were compared. For the fictitious leaf photosynthetic characteristics a capacity to adapt to the prevailing light conditions, that means the capacity to build "sun" and "shade" leaves, was presumed. The presumed sun and shade leaves were represented by different values of maximum assimilation rate $\left(A_{\max }\right)$, leaf respiration $\left(R_{\mathrm{d}}\right)$, initial slope of the photosynthetic light curve $(k)$, and light dependent stomatal opening $(s)$. In the model, these parameters were increased or decreased by $+30 \%$ or $-30 \%$, respectively. The assumption was based on values reported for woody species exhibiting photosynthetic acclimation to shade (for example: Fagus sylvatica [38], Corylus avellana [39]). The parameters were varied individually and in combinations representing sun and shade leaves (sun leaf: unchanged alder characeristics; shade leaf: $A_{\max }-30 \%, R$ $-30 \%, k+30 \%, s+30 \%)$. The growth of small trees with only shade or only sun leaves ("shade type" and "sun type") was compared to that of trees with the capacity to adapt their leaves to the low light conditions in the inner crown ("adaptive type"). Within the crown of the latter type, the gas exchange parameters were switched from sun to shade characteristics when the local irradiance was less than $50 \%$ of the incident irradiance. Model trees were grown either in isolation or in competition with each other.

In simulation runs with competing trees, their arrangement and distance ensured that the crowns of the growing trees overlapped during development. The arrangement of the three competing trees formed an equilateral triangel. In order to distinguish between the effects of mere spatial competition and those of the different leaf types, competition of identical trees was also taken into account.

\section{RESULTS}

\subsection{Individual variation of photosynthetic characteristics}

An increase of $A_{\max }$ by $30 \%$ resulted in a large increase in tree biomass $(+135 \%)$, while a decrease of $A_{\max }$ by $30 \%$ decreased tree biomass by $85 \%$ (table II). Increase and decrease of dark respiration by $30 \%$ produced the opposite effect, but to a lesser degree $(-16$ and $+9 \%$ ). Increased efficiency of carbon assimilation under low light conditions, given by a $30 \%$ higher $k$-value, resulted in a biomass increase of about $30 \%$. The effects of the variation of the initial slope of the photosynthetic light curve are therefore more pronounced (+28 and

Table II. Sensitivity of predicted tree growth to several leaf gas exchange characteristics: maximum assimilation rate $\left(A_{\mathrm{max}}\right)$, respiration of the leaves $\left(R_{\mathrm{d}}\right)$, initial slope of the light curve $(k)$, and light dependent stomatal opening $(s)$ varied by $\pm 30 \%$. Given is the $\%$ increase or $\%$ decrease in biomass after 150 time steps with the $30 \%$ change in the gas exchange characteristics, relative to the base case of sun leaves only $(=100 \%)$. The calculations are based on diurnal microclimatic courses of a very sunny and warm period during early summer 1992.

\begin{tabular}{lcccc}
\hline $\begin{array}{l}\text { variation of leaf gas } \\
\text { exchange characteristics: }\end{array}$ & $A_{\max }$ & $R_{\mathrm{d}}$ & $k$ & $s$ \\
\hline$+30 \%$ & +135 & -16 & +28 & +1 \\
$-30 \%$ & -85 & +9 & -61 & -4 \\
\hline
\end{tabular}




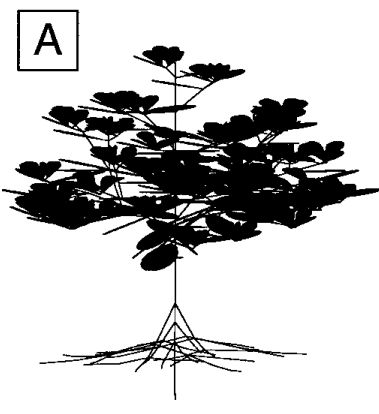

sun type
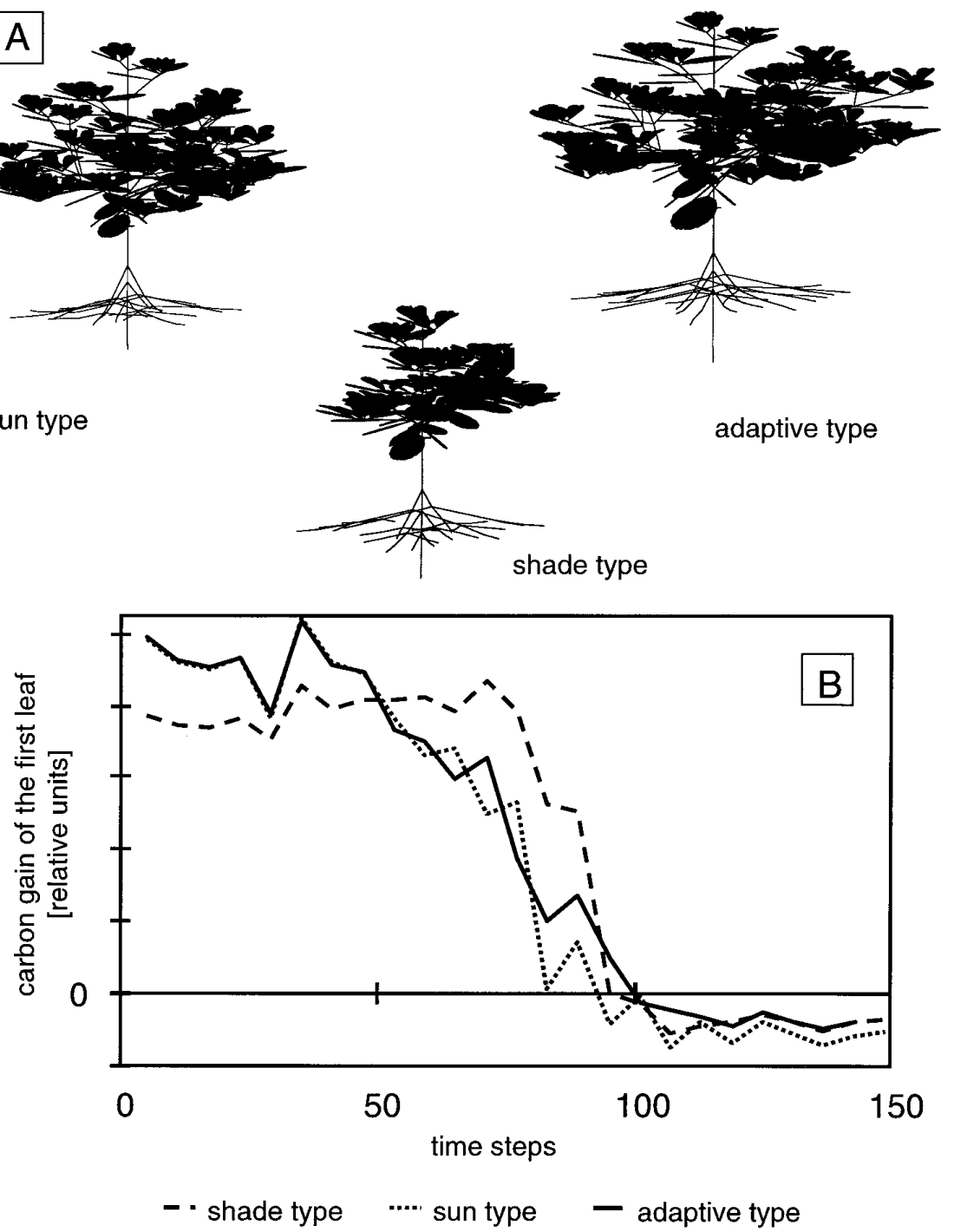

Figure 3. Three modelled trees, parameterised according to different photosynthetic types: sun type (exclusively sun leaves), shade type (exclusively shade leaves), adaptive type (sun and shade leaves distributed within the crown according to the local light conditions). A. Modelled trees after 150 time steps. B. Daily gas exchange of the first $(=$ most inner $)$ leaves during development.
$-61 \%)$ than the effects of the dark respiration. The variation of the light dependent stomatal opening showed only small influence $(+1$ and $-4 \%)$. The ranking of influence on tree growth was therefore: maximum photosynthesis rate $>$ initial slope of the photosynthetic light response curve $>$ dark respiration $>$ light dependent conductance.

\subsection{Single trees with different leaf types grown in isolation}

Modelled tree growth with exclusively shade leaves was less than that with exclusively sun leaves. The adap- tive type, however, was predicted to grow even better than the sun type (figure $3 A$ ). For trees grown in isolation, the leaf numbers of a sun type tree and an adaptive type tree were higher than those of the shade leaf type, but were of similar magnitude to each other during the first 130 time steps of simulation (figure 4).

During tree development, the calculated daily carbon acquisition of the oldest (= most inner) leaves of the three tree types differed in a typical manner (figure $3 B$ ). While the trees were small, no mutual shading occured, so that the inner leaves of the sun type and the adaptive type behaved identically. Each of these leaves gained more carbon than the first leaf of the shade type. At time step 48, however, light level within the crowns 

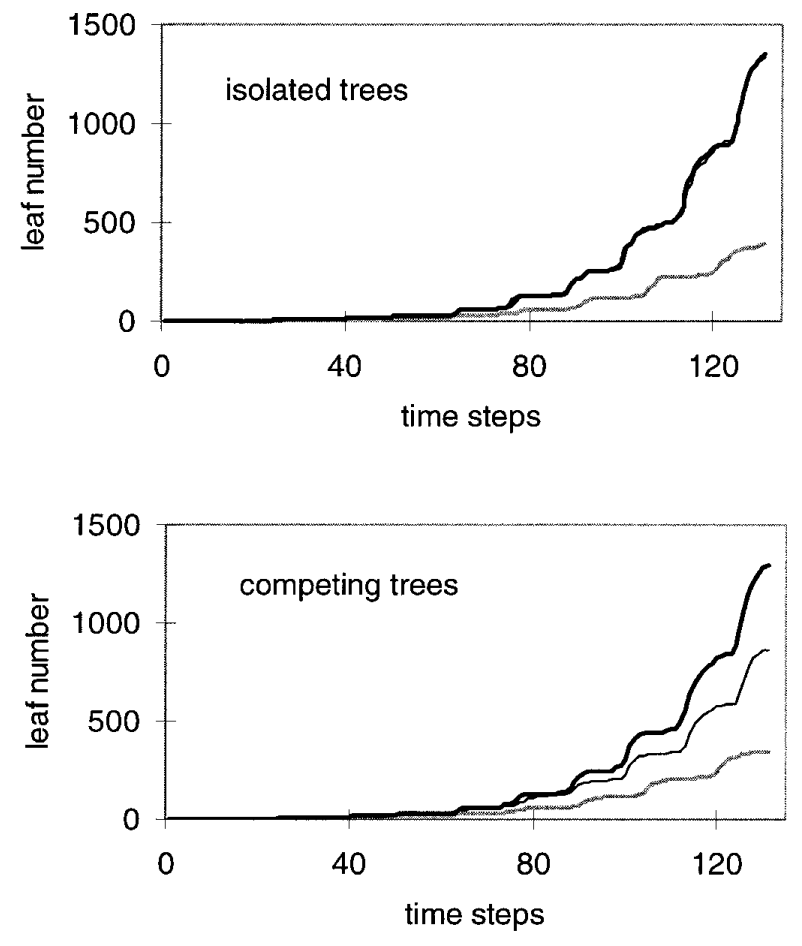

- shade type - sun type $\quad-$ adaptive type

Figure 4. Leaf numbers during development of three modelled trees, which are parameterised according to different photosynthetic types: sun type (exclusively sun leaves), shade type (exclusively shade leaves), adaptive type (sun and shade leaves distributed within the crown according to the local light conditions). A) single trees grown in isolation B) trees grown in competition with each other.

decreased to less than $50 \%$ of the external level. The first leaf of the adaptive type then switched its gas exchange from sun to shade characteristics. Thereafter, the sun type and the adaptive type grew more leaves than the shade type, so that mutual shading within their crowns increased more than in the crown of the shade type. Therefore, the first leaf of the shade type still assimilated more carbon than the first leaves of either of the other types. Subsequent differences between the carbon gain of the first leaves of the sun type and the adaptive type reflected the interplay between increasing total foliage and increasing number of adapted leaves. After time step 120, respiration played the most important role in the gas exchange of the inner leaves, so that the carbon loss of the adaptive leaf was identical to that of the shade leaf.
Table III. Total leaf numbers of modelled trees, grown either in islation or in competition with one or two other tree types, after 130 time steps. The tree types were sun type (exclusively sun leaves), shade type (exclusively shade leaves) and adaptive type (sun and shade leaves distributed within the crown according to the local light conditions).

\begin{tabular}{lccc}
\hline & \multicolumn{3}{c}{ total leaf number of a tree } \\
\cline { 2 - 4 } & shade type & sun type & adaptive type \\
\hline $\begin{array}{l}\text { isolated tree } \\
\text { (without competition) }\end{array}$ & 390 & 1.334 & 1.349 \\
$\begin{array}{l}\text { in competition with a } \\
\text { - shade type }\end{array}$ & 360 & 1.306 & 1.360 \\
- sun type & 299 & 1.009 & 1.114 \\
- adaptive type & 296 & 986 & 835 \\
$\begin{array}{l}\text { in competition } \\
\text { with both other types }\end{array}$ & 258 & 1.038 & 1.175 \\
\hline
\end{tabular}

\subsection{Competition between trees with different leaf types}

Growth differences between trees with different leaf types grown in isolation were accentuated when the trees were grown in competition with each other (figures 4 and 5). When only two different trees were grown together, each type grew best in competition with the shade type and showed lowest growth in competition with the adaptive type (table III). The results of the different 2-way competitions illustrate that the effect is not simply due to the fact that the subject tree has a neighbour but depends on the neighbour's type. While single trees of the adaptive type, when grown in isolation, reached $101 \%$ of the leaf number of the sun type, competition with both other types increased this advantage to $113 \%$. When all tree types were grown in competition with each other, the leaf numbers of the sun type and adaptive type trees diverged beyond time step 90, in contrast to growth in isolation where they were of similar magnitude for timestep <130 (figure 4). Competition between the three types enhanced the advantage of the adaptive type.

\section{DISCUSSION}

The model indicated that the ability of single leaves to acclimate to the local light conditions enhances whole tree growth and competitiveness. Previous calculations based on empirical measurements and process-based, physiological layer models have shown for Quercus coccifera, Qu. alba, Acer rubrum, and Eucalyptus globulus 

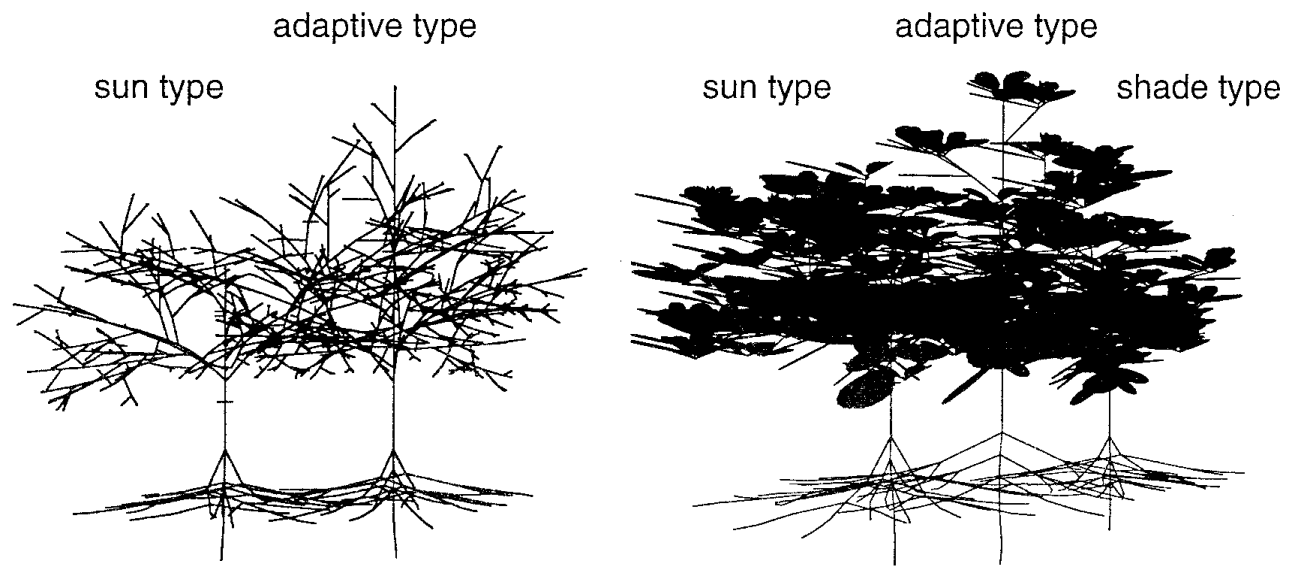

Figure 5. Two (left) or three (right) modelled trees grown in competition with each other (after 112 time steps). The trees are parameterised according to different photosynthetic types: sun type (exclusively sun leaves), shade type (exclusively shade leaves), adaptive type (sun and shade leaves distributed within the crown according to the local light conditions).

that physiological light acclimation increases plant carbon gain $[2,7,35]$. In these modelling approaches, however, calculations of matter fluxes were based on the assumption of an invariable structure of the system investigated. Because of their size and modular nature, trees have a large capacity to adjust physiological and structural attributes within a single genotype. In general, branch autonomy enhances the efficiency of exploitation of heterogeneous environments [29, 41]. Phenotypic plasticity is known to play an important role in plants' "foraging for light" [3].

Therefore, in order to explore the role of light acclimation of single leaves on whole-plant growth by modelling it is necessary to go beyond the assumption of invariable structure by using object-oriented models which reflect the functional modularity of plants.

Conventional system dynamic models operate with a fixed structure, where only state-variables and inputparameters can change. Their major limitation is the difficulty to represent structural changes of the modelled system during simulation runs, i.e. plant development. With functional-structural growth models it is possible to represent a variable, self-organized structure, which changes during simulation, according to the proceeding of the individual processes within the single objects. In a functional-structural tree growth model, plant development is not completely controlled by photosynthesis, but it is driven also by independently implemented morphological determinations. However, assimilate supply modifies the shaping of the modelled tree structure. Linking functional processes and structural developments makes it possible to study questions concerning quantitative relationships, which are sensitive to the specific local environment. The purpose of the present version of ALMIS was not to give a complete picture of tree growth, but rather to focus on the acclimation problem and to deliver a base for a more stringent discussion of the phenomenon. Nevertheless, the model has important limitations. While the processes dealing with carbon gain are quantitatively well represented, the processes of carbon allocation and carbon demand are only qualitatively known and represented.

The model of leaf photosynthesis was validated using independently measured diurnal courses of net photosynthesis [15]. Mutual shading within a canopy is a complex phenomenon, depending for example on leaf clustering, angle and orientation of the leaves as well as on solar azimuth and proportion of diffusive irradiance [e.g. 10, $24,34,42]$, but these features are mainly neglected in ALMIS. The model calculates irradiance attenuation within the crown following a combination of an object oriented and a homogeneous approach: the single cubes have different light regimes, but within one cube all leaves are treated uniformly. The dependencies of the calculated irradiance values on leaf area index (LAI) were close to those measured in the canopy of the alder forest [17].

For simplificity, the model represents only two types of leaves instead of a gradual transition between sun and shade leaves through the canopy. The leaves switch from sun to shade characteristics within one time step, whereas under natural conditions the adaption of leaves from high light to low light and vice versa occurs over 10 to 14 days. Because of these and other more general limitations, the present predictions of ALMIS should be interpreted only qualitatively. For example, by ranking different leaf photosynthetic characteristics, ALMIS illustrates the potential for studying effects of light acclimation of single leaves on whole plant growth. This modelling approach is valuable, because long-term whole tree 
responses are very difficult to measure, and yet the adaptive significance of spatially varying photosynthetic characteristics can only be assessed at the whole plant level.

The capacity to produce shade leaves was shown to have positive implications for the total number of leaves produced and the total biomass of the modelled trees: an adaptive type with the capacity to adapt the leaves to the low light conditions in the inner crown was predicted to grow better than tree individuals with exclusively shade or sun leaves. Moreover, competition with other types enhanced the advantage of the adaptive type for tree growth.

Because black alder does not appear to acclimate the photosynthetic apparatus of shaded leaves, the implication of the present results is that the occurence of mutual shading seriously limits the carbon gain of the adult alder canopy. In comparison to other trees producing sun and shade leaves, this limitation certainly contributes to the low competitiveness of black alder in European forests.

Concerning the question of why black alder leaves have not developed the ability of acclimation, it is important to remember that selection acts on the whole phenotype, not only on single traits. A failure of plasticity may reflect not the constraints of unsophisticated physiology, but rather selection for conservatism, which in turn may be driven by habitat conditions [43].

In competition with other tree species, adaptations occuring at other levels of the plants' organisation may (over)compensate for the effects described here. Using an object-oriented modelling approach, List \& Küppers [27] demonstrated the importance of the spatial occupation of several woody species of different successional phases for the species' competitive success. Costs of adaptation and the abscission of leaves and branches, with a negative carbon balance may also play a role. The most important factors might be nutrient and water relations, which were ignored here.

With these caveats in mind, we conclude that black alder trees would be more competitive if they were able to acclimate the photosynthetic apparatus to low light conditions by producing shade leaves.

\section{REFERENCES}

[1] Acock B., Reddy V.R., Designing an object-oriented structure for crop models, Ecol. Modell. 94 (1997) 33-45.

[2] Baldocchi D.D., Harley P.C., Scaling carbon dioxide and water vapour exchange from leaf to canopy in a deciduous forest. II. Model testing and application, Plant Cell Environ. 18 (1995) 1157-1173.
[3] Ballaré C.L., Scopel A.L., Sánchez R.A., Foraging for light: photosensory ecology and agricultural implications, Plant Cell Environ. 20 (1997) 820-825.

[4] Björkman O., Responses to different quantum flux densities, in: Lange O.L., Nobel P.S., Osmond C.B., Ziegler H. (Eds.), Encyclopedia of Plant Physiology, NS 12A, Springer, Berlin, Heidelberg, New York, 1981, pp. 409-444.

[5] Boardman N.K., Comparative photosynthesis of sun and shade plants, Ann. Rev. Plant Physiol. 28 (1977) 355-377.

[6] Breckling B., An individual based model for the study of pattern and process in plant ecology: an application of object oriented programming, EcoSys. 4 (1996) 241-254.

[7] Caldwell M.M., Meister H.-P., Tenhunen J.D., Lange O.L., Canopy structure, light microclimate and leaf gas exchange of Quercus coccifera L. in a Portuguese macchia: measurements in different canopy layers and simulations with a canopy model, Trees 1 (1986) 25-41.

[8] Cermak J., Solar equivalent leaf area: an efficient biometrical parameter of individual leaves, trees and stands, Tree Physiol. 5 (1988) 269-289.

[9] Dahl O.J., Myrhaug B., Nygaard K., SIMULA. Common base language, Oslo (Norwegian Computing Centre) 1968.

[10] Dauzat J., Simulated plants and radiative transfer simulations, in: Varlet-Grancher C., Bonhomme R., Sinoquet H. (Eds.), Crop structure and light microclimate, INRA, Paris, 1993, pp. 271-278.

[11] Deleuze C., Hollinger F., A transport model for tree ring width, Silva Fenn. 3 (1997) 239-250.

[12] Ellenberg H., Vegetation Mitteleuropas mit den Alpen, Ulmer Stuttgart, 1996.

[13] Ellsworth D.S., Reich P.B., Canopy structure and vertical patterns of photosynthesis and related leaf traits in a deciduous forest, Oecologia 96 (1993) 169-178.

[14] Eschenbach C., Zur Physiologie und Ökologie der Schwarzerle (Alnus glutinosa). On the physiology and ecology of black alder (Alnus glutinosa). Dissertation, University Kiel (1995) 197 pp.

[15] Eschenbach C., Modellierung der Primärproduktion der Schwarzerle (Alnus glutinosa). Modelling of primary production of black alder (Alnus glutinosa), Ecosys. 4 (1996) 195206.

[16] Eschenbach C., Zur Ökophysiologie der Primärproduktion der Schwarzerle (Alnus glutinosa (L.) Gaertn.). On the ecophysiology of primary production of black alder (Alnus glutinosa (L.) Gaertn.), Verh. Ges. Ökol. 26 (1996) 89-95.

[17] Eschenbach C., Kappen L., Leaf area index determination in an alder forest - A comparison of three methods, J. Exp. Bot. 47 (1997) 1457-1462.

[18] Eschenbach C., Modelling Growth and Development of Black Alder Trees with an Object Oriented Approach, Proceedings of the 24th Conference of the Association of SIMULA Users, ASU Newslett. 24 (1998) 75-86. 
[19] Evans J.R., von Caemmerer S., Adams III W.W. (Eds.), Ecology of photosynthesis in sun and shade, CSIRO, Melbourne, 1988.

[20] Früh T., Simulation of water flow in the branched tree architecture, Silva Fenn. 3 (1997) 275-284.

[21] Gansert D., Sprick W., Storage and mobilization of nonstructural carbohydrates and biomass development of beech seedlings (Fagus sylvatica L.) under different light regimes, Trees 12 (1998) 247-257.

[22] Givnish T.J., Adaptation to sun and shade: a whole plant perspective, Austr. J. Plant Phys. 15 (1988) 63-92.

[23] Hegi G., Illustrierte Flora von Mittel-Europa, Lehmann's Verlag, München, 1935.

[24] Kellomäki S., Strandman H., A model for the structural growth of young Scots pine crowns based on light interception by shoots, Ecol. Modell. 80 (1995) 237-250.

[25] Korpilahti E. (Ed.), Functional-Structural Tree Models, papers selected from the Helsinki Workshop on FunctionalStructural Tree Models, 12-13 September, 1996, Silva Fenn. 3 (1997) 239-380.

[26] Leitungsgremium des Ökosystemforschungsprojektes Bornhöveder Seenkette und Vorstand des Vereins zur Förderung der Ökosystemforschung zu Kiel e.V. (Eds.), Ökosystemforschung im Bereich der Bornhöveder Seenkette, Arbeitsbericht 1988-1991, EcoSys. 1, 1992.

[27] List R., Küppers M., Kohlenstofferwerb und Kronenarchitektur von Holzgewächsen in Konkurrenzsituationen - Messung an Einzelzweigen, Modellierung für Pflanzengruppen, EcoSys. Suppl. 20 (1997) 89-99.

[28] Monsi M., Saeki T., Über den Lichtfaktor in den Pflanzengesellschaften und seine Bedeutung für die Stoffproduktion, Jpn. J. Bot. 14 (1953) 22-52.

[29] Nilsen E.T., Orcutt D.M., The physiology of plants under stress, abiotic factors, John Wiley \& Sons, INC, New York, 1996.

[30] Osmond C.B, Chow W.S., Ecology of photosynthesis in the sun and shade: summary and prognostications, Austr. J. Plant Physiol. 15 (1988) 1-9.

[31] Pearcy R.W., Yang W., A three-dimensional shoot architecturel model for assessment of light capture and carbon gain by understory plants, Oecologia 108 (1996) 1-12.
[32] Pearcy R.W., Sims D.A., Photosynthetic acclimation to changing light environments: scaling from the leaf to the whole plant, in: Caldwell M.M., Pearcy R.W. (Eds.), Exploitation of environmental heterogeneity by plants: ecophysiological processes above and below ground, Academic Press, San Diego, 1994, pp. 145-174.

[33] Pugnaire F.I., Valladares F., Handbook of functional plant ecology, Marcel Dekker, New York, 1999.

[34] Ross J., The radiation regime and architecture of plant stands, Dr. W. Junk Publishers, The Hague, 1982.

[35] Sands P.J., Modelling canopy production. II. From single-leaf photosynthetic parameters to daily canopy photosynthesis, Austral. J. Bot. 69 (1995) 603-614.

[36] Schleuß U., Böden und Bodeneigenschaften einer Norddeutschen Moränenlandschaft - Ökologische Eigenschaften, Vergesellschaftung und Funktionen der Böden im Bereich der Bornhöveder Seenkette, EcoSys. Suppl. 2, 1992.

[37] Schrautzer J., Härdtle W., Hemprich G., Wiebe C., Zur Synökologie und Synsystematik gestörter Erlenwälder im Gebiet der Bornhöveder Seenkette (Schleswig-Holstein), Tuexenia 11 (1991) 293-307.

[38] Schulte M., Saisonale und interannuelle Variabilität des $\mathrm{CO}_{2}$-Gaswechsels von Buchen (Fagus sylvatica L.) Bestimmung von C-Bilanzen mit Hilfe eines empirischen Modells, Verlag Shaker, Aachen, 1992.

[39] v.Stamm S., Untersuchungen zur Primärproduktion von Corylus avellana an einem Knickstandort in SchleswigHolstein und Erstellung eines Produktionsmodells, EcoSys Suppl. 3 (1992) 166.

[40] Sievänen R., Nikinmaa E., Perttunen J., Evaluation of importance of sapwood senescence on tree growth using the model LIGNUM, Silva Fenn. 3 (1997) 329-340.

[41] Sprugel D.G., Hinckley T.M., Schaap W., The theory and practice of branch autonomy, Ann. Rev. Ecol. Syst. 22 (1991) 309-334.

[42] Stenberg P., Penumbra in within-shoot and betweenshoot shading in conifers and its significance for photosynthesis, Ecol. Modell. 77 (1995) 215-231.

[43] Valladares F., Architecture, ecology, and evolution of plant crowns, in: Pugnaire F.I., Valladares F. (Eds.), Handbook of functional plant ecology, Marcel Dekker, New York, 1999. 